\title{
EQUALITY AND CHALLENGES IN EMPLOYMENT RELATIONSHIP BASED ON KOSOVO LEGAL RESOURCES
}

\author{
Bashkim Rrahmani ${ }^{408}$
}

DOI: https://doi.org/10.31410/eraz.2018.781

\begin{abstract}
The employment relationships in Kosovo are regulated by many legal acts beginning with the Kosovo Constitution. Kosovo Constitution serves as the main resource of the employment law and then there is a considerable number of legal acts which could be used as the resources of the employment law. As the resource of the employment law there are a series of international legal acts that are directly applicable in Kosovo. Based on these resources there is a legal system in place which regulates the rights and the obligations that derive from the employment relationship. Among these resources Kosovo Labor Law is the main legal act applicable for employers and employees in the public and the private sector. Implementation of Labor Law and other legal resources in sense of employment relationships has not been an easy process in ensuring equal opportunities and in avoiding discrimination during the entire process: from hiring up to contract termination, as well as the protection of employees during the time they are working and especially in cases of contract termination. Author of this paper by using a combined methodology and with the methods of systemic analysis, method of comparison, etc., will stress out all forms of violation of laws in this field and will come up with the recommendations which could be used by employers and employees and those responsible to protect the rights of employees. The paper and especially findings, conclusions and the recommendation could be used as a resource for further academic debates.
\end{abstract}

Key words: employers, employees, constitution, law, contract, termination

\section{Introduction}

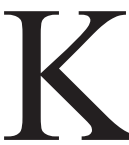

osovo passed through various periods in sense of establishing the system of labor relations. This paper does not cover the period before 1999, whereas it is known that L 1999 Kosovo was put under the international civil administration. UNMIK executed its power based on the UN Security Council Resolution 1244. UNMIK laws were regulations and the main regulation regarding the labor relations was the Regulation No.2001/27 titled Regulation on Essential Labor Law in Kosovo.

Section 9, regulates the employment relationships, explaining at the beginning who the parties of an employment relationships are. According to this the first party is,

An employer means a natural or legal person who provides an employee with work, and pays him/her a salary/wage for the work or services performed. An employer performs its obligations, and may exercise its rights, in accordance with the applicable law, labor contract, and, where applicable, collective agreement. ${ }^{409}$

The second which enters into the employment relationships based on the contract, as

\footnotetext{
${ }^{408}$ College AAB, Pristina

${ }^{409}$ Section 9.2, Regulation on Essential Labor Law in Kosovo, No.2001/27
} 
An employee means a natural person employed to perform work or services for an employer, under the latter's authority and control. An employee performs his/her obligations, and may exercise his/her rights, in accordance with the applicable law, labour contract, and, where applicable, collective agreement. ${ }^{410}$

This regulation regulates basically the entire area of the modern labor law from the beginning giving the minimal age when a person can start to work; labor contract, form of the contract, the rights of creating unions, medical leave, leave without pay, etc. In general, the regulation covered the entire field of the labor law but it is a matter of question if practically it was applied with the success. There were also many issues it did not cover and thus did not regulate. To this it will not also be mentioned the issue of employees within the international organizations was regulated or how the regulation was applied for them. Nonetheless, it was necessary to say that there was a regulation/law on that time. Of course, in various issues it was far from the standards regulated by the laws in the other countries of Europe. However, formally covered the important issues it the time and the UNMIK regulations were parts of the so called applicable law in Kosovo. Therefore, labor law in form and in definitions was similar to the law and laws of developed countries and the developed democracies, but of course in the practical sense of being applied and in protecting employees issues are quite different. Let us see how labor law is defined in EU and when we conclude that formally the labor law in Kosovo was similar to the EU labor law for this we cannot be criticized.

Labor law defines your rights and obligations as workers and employers. EU labor law covers 2 main areas:

- working conditions: working hours, part-time \& fixed-term work, posting of workers and;

- informing \& consulting: workers about collective redundancies, transfers of companies, etc. ${ }^{411}$ From the main areas that EU labor law covers, the legislation on the UNMIK time as given above and under the current circumstances the areas covered are similar. Problems on the equality are more of application of laws, policies, etc., nature, rather than the lack of legislation.

\section{Kosovo labor law and its application}

Kosovo Parliament 2010 adopted the Law on Labor by which the main areas of employment were covered. The Law contains 100 articles divided into twelve chapters. It is important to be said that even though this is the basic law to regulate the labor law, there are several laws which should be always analyzed when the labor law is discussed. Thus Law on the Civil Service of the Republic of Kosovo, Law on the Protection from Discrimination, Law on Gender Equality, EU legislation and naturally Kosovo Constitution contain additionally create a general basis for a sound labor law in Kosovo. Let us see how issues are regulated with the Kosovo Labor Law and its interaction with the other laws.

From the Chapter one it is important to take the following:

1. Provisions of this Law shall be applicable for employees and employers in the private and public sector in Republic of Kosovo. 2. Provisions of this Law shall be applicable for employees and employers, whose employment is regulated through a special Law, if the special Law does not provide for a solution for certain issues deriving from employment relationship. 3. Provisions of this Law shall be applicable for foreign

\footnotetext{
${ }^{410}$ Section 9.3, Regulation on Essential Labor Law in Kosovo, No.2001/27

${ }^{411} \mathrm{http}$ ://ec.europa.eu/social/main.jsp?catId=157\&langId=en (accessed 17.05.2018)
} 
citizenship employees and persons without citizenship, who are employed to employers within territory of Republic of Kosovo, unless otherwise provided by Law. 4. Provisions of this Law shall not be applicable to employment relationships within international missions, diplomatic and consular missions of foreign states, International Military Presence established in the Republic of Kosovo under the Comprehensive Proposal for the Status Settlement and international governmental organizations. ${ }^{412}$

This article gives exact data about what this law covers and it explains issues about its application when we have to deal with the special laws, for foreign citizens working in Kosovo etc. Kosovo Labor Law forbids discrimination in "recruitment, training, promotion of employment, terms and conditions of employment, disciplinary measures, cancellation of the contract of employment or other matters arising out of the employment relationship and regulated by Law and other Laws into force". ${ }^{413}$ Provisions of this law, in regard to discrimination orient to the direct application of the special law, which in this case is Law on the Protection from Discrimination. This Law talking about the protection from discrimination with its purpose creates a framework for prevention and combating discrimination in all possible basis, thus consequently in the labor law. In this regard it serves as the special law. Whereas,

This law is in accordance with Council Directive 2000/43/EC of 29 June 2000 on implementing the principle of equal treatment between persons regardless of racial or ethnic origin of the Council of the European Union, Council Directive 2000/78/EC of 27 November 2000 on establishing a general framework for equal treatment in employment and occupation of the Council of the European Union, Council Directive 2004/113/EC of 13 December 2004 on implementing the principle of equal treatment between men and women in the access to and supply of goods and services of the Council of the European Union, Directive 2006/54/EC of the European Parliament and of the Council of 5 July 2006 on implementation of the principle of equal opportunities and equal treatment of men and women related to employment and occupation (amended) of the European Parliament and the Council of the European Union. ${ }^{414}$

Talking to the special laws, it is important to stress out very similar disposal taken from the Law on Gender Equality, which is important to be cited, and which says,

This Law is in accordance with the Convention on the Elimination of All Forms of Discrimination against Women (CEDAW); Directive on establishing a general framework for equal treatment in employment and occupation (Directive 2000/78/EC); Directive on the implementation of the principle of equal opportunities and equal treatment of men and women in matters of employment and occupation (Directive 2006/54/EC); The Directive on the progressive implementation of the principle of equal treatment for men and women on issues of social security (Council Directive 79/7/EEC, of 19 December 1978); Directive on the application of the principle of equal treatment between men and women engaged in an activity in a self-employed capacity and repealing Council Directive 86/613/EEC (Directive 2010/41/EU, of 7 July 2010); Directive on the implementing the principle of equal treatment between men and women in the access to and supply of goods and services (Directive 2004/113/EC). ${ }^{415}$

\footnotetext{
412 Article 2, Kosovo Law on Labor

${ }^{413}$ Article 5, Kosovo Law on Labor

${ }^{414}$ Article 1, paragraph 2, Law on the Protection from Discrimination

${ }^{415}$ Paragraph 3, Article 1, Kosovo Law on Gender Equality
} 
It was already said that there is a sound set of laws that regulate the areas of labor law and it is also said that the biggest challenge is the application of these laws. In order to give some more details on labor laws, for the needs of this paper some more disposals of this law should be mentioned. Not necessarily to be cited. In the Chapter two, titled Establishing Employment Relations, it is important to especially mention that the employment relationship cannot be concluded with a person bellow fifteen (15) years of age. Further, in this chapter there are disposals that regulate the issue of public competition for the public sector and the employment of foreigners. ${ }^{416}$ The law specifies the types of contracts which may be concluded on employment, and they are: contracts for an infinite period; contracts for a fixed period of time and contracts for specific tasks and duties. ${ }^{417}$

Chapter three of the law, titled Systematization of Employees in Working Posts regulates issues of commissioning of employees in working posts; temporary reassignment; and reassigning an employee with consent. Chapter four/working hours, where full time working hours shall be forty (40) hours per week, whereas for an employee under 18 years of age shall not exceed 30 hours per week. ${ }^{418}$ To this chapter belong also the issues of part-time working hours; reduced working hours; extended working hours; division and modification of working hours; prohibition and extension of working; and night shifts.

Chapter five/breaks and absences from work regulate issues of break during working hours; adopting the break to the labor process; daily rest; weekly rest; annual leave; annual leave for education sector employees; annual leave on the day of official holidays; first time annual leave; part of annual leave in proportion with the time spent at work; the schedule for the use of annual leave; compensation if the annual leave is not used; paid absence from work; unpaid absence from work; and temporary suspension of rights and duties deriving from employment relationships.

Chapter six/occupational protection and safety regulate issues of general occupational protection; commissioning of an employee for hazardous tasks; protection of youth, women and persons with disabilities; protection of motherhood; maternity leave; the rights of child's father; maternity leave in the case of the death of the infant; absence from work due to special care for the child; prohibition on termination of contract, where it is important to be given as follows:" During pregnancy, maternity leave and absence from work due to special care for the child, the employer shall not terminate the contract with the

\footnotetext{
416 See articles 7,8,9 of the Kosovo Law on Labor

417 Article 10, Paragraph 2, Kosovo Law on Labor

${ }^{418}$ Article 20, Kosovo Law on Labor
}

Bashkim Rrahmani is an expert in Kosovo and a lecturer of EU, International Law, Constitutional Law,etc. Now he works as the Prof. Ass. for the Coellege AAB in Prishtina. Prior to this he has worked as the lecturer at the Haxhi Zeka University and Universum College (both Kosovo). Before this he was an Executive Director of the Foundation for Democratic Initiative (2001-2011), one of the most active civil society organizations in Kosovo. During 1994-2000, he acted as an Education as well as a Labour Inspector. Around this period he also regularly visited Washington as well as Kosovo, Macedonia and Albania in the position of Field Representative. Where he reported the political, economic and social situation of the three countries for the Krieble Institute of the Free Congress Foundation. He is an author of a number of scientific publications, and he has participated in dozens of international scientific conferences. Since 2008, he is a national trainer of trainers in Acquis Communautaire and from 2011, a national certified \& licensed mediator. 
employee and/or make a transfer to another post, except in cases of termination of the contract according to Article 76 of this Law" ${ }^{\prime 419}$, and notice on temporary incompetency for labor.

Chapter seven/salary and benefits of employees covers salary, salary compensation and other income; allowances; minimum salary; compensation of salary; compensation of sick leave; compensation for occupational injuries; absence from work due to insecurity and health protection; compensation of expenses for official visits; compensation of damage by the employee; proportional compensation of damage; compensation of damage to the employer; and compensation according to other applicable version.

Chapter eight/termination of employment relationships covers the issues of termination of employment contact on legal basis; termination of employment contract with the agreement; unilateral termination of the contract by the employee; termination of employment contract by the employer; notification period for termination of employment contract; procedure to the termination of contract; temporary suspension from work; compensation of salary during the temporary suspension; duration of temporary suspension; collective dismissals; and retirement.

Chapter nine/procedures for the exercise of rights deriving from employment relationships cover the issues of protection of employees' rights; protection of the employee by the court; court decision on termination of employment contract; protection of rights through mediation; protection of employee by the labor inspectorate; disciplinary measures; employee's responsibility; disciplinary measures for the violation of labor duties; imposition of measures; and timeline for submission.

Chapter ten/organizations of employees and employers covers the issues of freedom of tradeunion organization; the right to strike; collective contract; and labor card.

Chapter eleven/punitive provisions covers issues of fines and funds collected from fines.

The last chapter twelve/provisional and final provisions covers the issues of supervision; harmonization of employer's acts; exercising the rights and provisions in force; public services of employment; issue of sub - legal acts; abrogation of legal acts; and entry into force of this law.

\section{Equality and challenges}

Equality means "the right of different groups of people to have a similar social position and receive the same treatment: equality between the sexes; racial equality; the government department responsible for equalities..."420. As it was seen, law on labor and other special laws applied in the area of labor law provide sound legal basis for the equality. But in practice the violation of the norms of equality are seen in various forms. Kosovo has a very high unemployment rate and getting a job is already similar to winning a jack pot. Thus conclusion of contract and termination of contracts are perhaps issues where the disposal of law are violated quite a lot. Regarding the private sector, a considerable number of employees have no labor contracts, and this present violation of laws and continual insecurity by increasing the fear of employees of being dismissed from the job without procedures and with no possibilities for

\footnotetext{
${ }^{419}$ Article 53, Kosovo Law on Labor

${ }^{420} \mathrm{https}$ ://dictionary.cambridge.org/us/dictionary/english/equality (accessed on 29.06.2018)
} 
appeal. ${ }^{421}$ Employees in the private sector enter into the working relations factually but formally, there is no legal formal act signed. This is considered one of the main reasons why employees in the private sector do not denounce and do not witness openly the violations of their rights from the employers. ${ }^{422}$ However, there are also employees of the public sector that rarely decide to denounce employer for the violation of their rights. Here we may find other additional reasons why they do not undertake acts of appealing or why they do not enter into the processes of realizing their rights when their rights were violated. They hardly decide to initiate the procedures in court, when they were for example expelled from their job as a result of misuse of power of the employer (director or any other person responsible to hire and fire). They do not do this because the procedures in court last for ages and none will be pleased with the final court decision no matter how satisfactory that decision might be. ${ }^{423}$ It may be subject of the other paper to explain why procedures take so long, even in the cases of labor law when laws itself require development of emergency procedures or the procedures to be treated with the priority.

The issue of employees in the public sector needs much more analysis when we discuss about labor law. State actually is the biggest employer where various analysis show that the employment in the public sector is quite politically colored, meaning that politics has a very big impact in the hiring processes. Moreover, EU Commission goes with,

Kosovo is at an early stage of preparation on social policy and employment. There has been some progress during the reporting period. The Employment Agency is now functional, public employment services have been improved and further alignment on health and safety at work has been achieved. At the same time, fatal incidents at work are increasing and the General Collective Agreement is still not implemented. ${ }^{424}$

EU Commission with the last report as well as with all previous reports gives the findings and gives the recommendations for improvement. For the needs of this paper it is very important to give the following taken from the last Progress Report that goes,

High inactivity and low employment remain among key challenges. The overall activity rate stood at $37.6 \%$ in 2015 and the employment rate was extremely low at $25 \%$. In addition to that, the unemployment rate is still very high at $31 \%$ in 2017 . It continues to be higher for women $(37 \%)$ than for men $(29 \%)$. The overall employment rate is 30 $\%$, but only $13 \%$ of women are in formal employment, compared to $47 \%$ of men. Only $29 \%$ of the employed have permanent work contracts, whereas $71 \%$ work on shortterm contracts. Unemployment is most prevalent among young people (15-24 years), with $51 \%$ unemployed. The rates of unemployment are even higher in the Roma and Ashkali communities. The members of these communities usually work in the informal

\footnotetext{
$421 \quad$ http://www.ombudspersonkosovo.org/sq/lajme/INFORMATE-LIDHUR-ME-TE-DREJTAT-NGAMARREDHENIA-E-PUNES-1407 (accessed on 17.05.2018)

422 http://www.ombudspersonkosovo.org/sq/lajme/INFORMATE-LIDHUR-ME-TE-DREJTAT-NGAMARREDHENIA-E-PUNES-1407 (17.05.2018)

${ }^{423}$ A person XX (known for the author) was dismissed from her position at the institution of high education within a day without any procedure, without any reason...etc., and there are already four years this person couldn't get the final court decision. It is hard to foresee if there are still more years until this person will get the final court decision, whereas it is very clear that based on the labor law this person will win the case. But is that decision going to be satisfactory after so many years?

424 Kosovo 2018 Report, https://ec.europa.eu/neighbourhood-enlargement/sites/near/files/20180417-kosovoreport.pdf, pg.59 (accessed on 29.06.2017)
} 
sector, holding unsecured, unqualified and low status jobs. Only a small number is registered as unemployed. ${ }^{425}$

Above it was said that there is a sound legal basis for a sound employment relationships, which obviously needs to be subject of changes. Requests for changes come from both, international and local factors. Problems are identified by various subjects and they can be classified easily. Thus, Ombudsperson of Kosovo has mentioned as follows: problems of labor relations as: lack of contracts, non-respect of daily, weekly, annual leave, birth leave, security in working place, discrimination regarding salaries, etc., appear basically as a consequence of high level of tax evasion (informal economy, tax evasion) with the purpose of profit by employer. ${ }^{426}$

The issue of labor law can be subject of various analysis with various approaches and all of them when analyzing and while finding short comings should not justify shortcomings with the slogan that we are talking about new state where shortcomings and weaknesses are common for these stages of state development.

\section{Conclusions}

The labor law in Kosovo has passed through an evaluation process and before anything is said, it is useful to conclude that the issue of laws and their implementation should be analyzed. The position of the employees differs a lot in both sectors: public and the private. In the public sector the form of discrimination is more difficult to be stressed out since formally employer pays attention to the formal procedures which are violated behind the scene. Actually formal procedures in these cases are respected but overall the process is behind the curtains. The current Labor Law should be changed especially respecting the EU suggestions. Courts should treat labor cases with high priority, because it is for ages know that "justice delayed is justice denied". The competences of labor inspectorates should be broadened and inspectors should be given more authority so they can intervene more quickly and take measures against especially officials who misuse power particularly when treating the rights of employees. Measures and penalties against these officials which misuse power should be stronger and they should be regulated strictly by the laws. The misuse of their power, for example when an employee was expelled can be classified at least of two channels talking about consequences. First, employee's rights were violated and all he/she faces is achievement of the delayed justice. Second, when he/she achieves delayed/denied justice, compensation is done from tax-payers whereas nothing happens to the official who has created such a situation. Therefore measures against the misuse of power should be precisely regulated. Mechanisms of collective contracts should be put in place and respected when signed by employers.

\section{Literature}

[1]. Bujupi, Hava. E Drejta e Punës, Universiteti I Prishtinës, Prishtinë, 2014.

[2]. Çela, Kudret. E Drejta e Punës, ILAR, Tiranë, 2012.

[3]. http://www.ombudspersonkosovo.org/sq/lajme/INFORMATE-LIDHUR-ME-TEDREJTAT-NGA-MARREDHENIA-E-PUNES-1407 (accessed, 17.05.2018)

[4]. Kosovo 2018 Report, https://ec.europa.eu/neighbourhoodenlargement/sites/near/files/20180417-kosovo-report.pdf (accessed 29.06.2018)

\footnotetext{
${ }^{425}$ Kosovo 2018 Report, https://ec.europa.eu/neighbourhood-enlargement/sites/near/files/20180417-kosovoreport.pdf, pg.59-60 (accessed on 29.06.2017)

426 http://www.ombudspersonkosovo.org/sq/lajme/INFORMATE-LIDHUR-ME-TE-DREJTAT-NGAMARREDHENIA-E-PUNES-1407 (17.05.2018)
} 
[5]. Kosovo Constitution, available at: http://www.kryeministriks.net/repository/docs/Constitution1Kosovo.pdf (as of 29.06.2018),

[6]. Kosovo Law on Gender Equality, available at: http://www.assemblykosova.org/common/docs/ligjet/05-L-020\%20a.pdf (as of 29.06.2018)

[7]. Kosovo Law on Labour , available at: http://www.assemblykosova.org/common/docs/ligjet/2010-212-eng.pdf (as of 29.06.2018)

[8]. Kosovo Law on the Protection from Discrimination, available at: https://www.kuvendikosoves.org/common/docs/ligjet/05-L-021\%20a.pdf (as of 29.06.2018)

[9]. Law on the Civil Service of the Republic of Kosovo 2010

[10]. Ligji i Punës: gjashtë muaj pas hyrjes në fuqi - GAP Analizë Politikash - Qershor 2011

[11]. Regulation on Essential Labour Law in Kosovo 2001/27 